\title{
The first 'lost year' of Mediterranean sea turtles: dispersal patterns indicate subregional management units for conservation
}

\author{
Paolo Casale $^{1,2, *}$, Patrizio Mariani $^{3}$ \\ ${ }^{1}$ Department of Biology and Biotechnologies 'Charles Darwin', University of Rome ‘La Sapienza', viale dell'Università 32, \\ 00185 Roma, Italy \\ ${ }^{2}$ Centre for Ecology \& Conservation, University of Exeter, Cornwall Campus, Cornwall TR10 9EZ, UK \\ ${ }^{3}$ Center for Ocean Life, National Institute for Aquatic Resources, Technical University of Denmark, Kavalergaarden 6 , \\ 2920 Charlottenlund, Denmark
}

\begin{abstract}
Identifying highly frequented areas is a priority for sea turtle conservation, and the distribution of young individuals in open waters represents a major knowledge gap due to methodological biases. The drift of hatchlings from 38 loggerhead Caretta caretta and 10 green Chelonia mydas turtle nesting sites in the Mediterranean was simulated for the first 6 mo of life, with simulations repeated for 5 different years (2001 through 2005). Results indicate that hatchlings from the Levantine and south-central Mediterranean sites are mainly retained in the same areas of origin, while those from the Ionian area mainly disperse to the Ionian, Adriatic and southcentral Mediterranean areas. Combining hatchling dispersal with existing empirical information on juveniles and adults, a general distribution model among nesting sites, and oceanic and neritic foraging grounds for Mediterranean sea turtles is proposed. The Levantine zone may be particularly key for the conservation of the Mediterranean populations of both species, since it may host the highest concentration of individuals. Subregional management units identified by dispersal patterns may facilitate turtle conservation through a relatively small-scale international approach. In-water studies in specific zones are identified as a research priority for improving current knowledge and informing conservation plans.
\end{abstract}

KEY WORDS: Caretta caretta Chelonia mydas $\cdot$ Loggerhead turtle $\cdot$ Green turtle $\cdot$ Dispersal · Conservation $\cdot$ Mediterranean

\section{INTRODUCTION}

Sea turtles are wide-ranging animals, and potentially face a large number of threats throughout their distributional range, which may include multiple countries (e.g. Nichols et al. 2000, Broderick et al. 2007, Witt et al. 2011, Schofield et al. 2013). The implementation of conservation measures is, therefore, particularly challenging, and detailed knowledge of the turtles' distribution, range and habitats is key to generating effective conservation approaches.

Three sea turtle species occur in the Mediterranean (Casale \& Margaritoulis 2010): the leatherback turtle Dermochelys coriacea, the green turtle Chelo- nia mydas, and the loggerhead turtle Caretta caretta. Leatherback turtles enter the Mediterranean in small numbers from the Atlantic but do not breed in the basin. The other 2 species have Mediterranean populations recognized as regional management units, and the green turtle unit in particular is considered at high risk (Wallace et al. 2011). The main identified threats at sea to these 2 Mediterranean populations are incidental catch in fishing gear, collision with boats, and intentional killing (Casale \& Margaritoulis 2010). These threats increase overall mortality (Casale et al. 2007c, Casale et al. 2010) and, as a whole, represent a high level of threat (Wallace et al. 2011). Identifying the most frequented areas by these 2 sea 
turtle species could potentially inform conservation plans for their respective Mediterranean populations (e.g. Schofield et al. 2013).

The loggerhead turtle is the most abundant sea turtle species in the Mediterranean, and reproduces mainly in Greece, Turkey, Cyprus and Libya (Casale \& Margaritoulis 2010). Loggerhead turtles frequent the entire marine area of the Mediterranean, with high occurrences reported in the oceanic zones of (1) the westernmost part of the basin (from the Alboran Sea to the Balearic Islands), where most individuals are of Atlantic origin (Carreras et al. 2006), (2) the Strait of Sicily, and (3) the Ionian Sea. Loggerheads are also found in high abundance in the neritic zones in the north Adriatic, off Tunisia-Libya, off Egypt, and off the southeast coast of Turkey (Casale \& Margaritoulis 2010). Green turtles primarily reproduce on nesting beaches in Turkey, Cyprus and Syria (Casale \& Margaritoulis 2010). They primarily occupy neritic areas in the easternmost part of the basin, in addition to foraging areas in Greece and Libya (Casale \& Margaritoulis 2010).

Current knowledge on the distribution of sea turtles in the Mediterranean waters is based on data from strandings (Tomás et al. 2008, Casale et al. 2010, Türkozan et al. 2013), incidental catch in fishing gear (reviewed by Casale 2011), tag returns (Margaritoulis et al. 2003, Casale et al. 2007b, Revelles et al. 2008), satellite tracking (e.g. Bentivegna et al. 2007, Broderick et al. 2007, Revelles et al. 2007b, Schofield et al. 2013), genetic markers (e.g. Carreras et al. 2006, Garofalo et al. 2013), and aerial surveys (Gomez de Segura et al. 2006, Lauriano et al. 2011). However, most observations relate to the western and central Mediterranean, while less information is available for the easternmost part (the Levantine basin). Moreover, the turtles studied by the above methods are often adults or large juveniles above $50 \mathrm{~cm}$ curved carapace length $(\mathrm{CCL})$; whereas the distribution of the elusive small turtles $<40 \mathrm{~cm} \mathrm{CCL}$, corresponding approximately to the first $7 \mathrm{yr}$ of life (Casale et al. 2009b, 2011a,b), represents the main knowledge gap. This is a common problem worldwide, with the first period of life of sea turtles also known as 'lost years' (Carr \& Meylan 1980), because individuals are small, usually live in open waters and are generally difficult to observe.

Studying small turtles in the wild is labour-intensive (e.g. Witherington et al. 2012), and thus preliminary insights into the potential distribution patterns of turtles and locations of high density areas may promote future studies. Evidence is mounting that numerical models coupling ocean circulation and particle tracking are able to reconstruct dispersal patterns of hatchling sea turtles in the Mediterranean (Zakynthos island, Greece; Hays et al. 2010) and elsewhere (e.g. Okuyama et al. 2011, Putman et al. 2012, Shillinger et al. 2012). Hatchling sea turtles have limited swimming capacity and are often considered to be passive drifters, possibly aggregating in convergence zones (e.g. Witherington et al. 2012). Satellite tracking and genetic data indicate that currents may also affect, at least in part, the distribution of much larger turtles (Carreras et al. 2006, Bentivegna et al. 2007, Revelles et al. 2007b, Lambardi et al. 2008, Monzón-Argüello et al. 2010). Moreover, it has been suggested that the distribution of loggerhead hatchlings and small juveniles may determine the areas frequented by larger individuals in the Mediterranean (Casale et al. 2007b, Hays et al. 2010). Hence, although limited to the first months of life, the dispersal pattern of hatchlings may provide useful indications about sea turtle distribution, especially in a relatively small basin such as the Mediterranean Sea.

By simulating hatchling drift from loggerhead and green turtle nesting sites in the Mediterranean, this study aimed to identify likely developmental areas for the first months of life of Mediterranean sea turtles hatched in different coastal sectors. This new information along with the existing distribution data may help identify developmental areas that are potentially shared by turtles originating from different nesting sites, thereby representing potential management units for conservation.

\section{MATERIALS AND METHODS}

In the first 6 mo of life, loggerhead and green turtle hatchlings are assumed to drift passively on the ocean currents of pelagic waters (e.g. Putman et al. 2012) because they do not attain buoyancy or dive capabilities until after $1 \mathrm{yr}$ of age (loggerheads: Milsom 1975). Furthermore, loggerhead and green turtles feed upon pelagic prey in the first period of their life, and then switch to benthic prey and seagrasses or algae, respectively (Bjorndal 1997). In the Mediterranean, isotopic signatures indicate that the 2 species still have a similar diet at a size of $25 \mathrm{~cm}$ CCL (Cardona et al. 2010), corresponding to an age $>2 \mathrm{yr}$ (Casale et al. 2009a, Goshe et al. 2010).

In this study, simulations of the dispersal of sea turtle hatchlings in the Mediterranean were performed using a total of 38 and 10 nesting sites of loggerhead and green sea turtles, respectively. These included 
Fig. 1. Eastern Mediterranean basin showing the $200 \mathrm{~m}$ isobath. Circles indicate major nesting sites of loggerhead (red), green sea turtles (green), and both species (blue) (Casale \& Margaritoulis 2010; see Table 1 for numbering). As an optimization of the dispersal simulation, in certain cases 2 or more sites have been aggregated. Red triangles indicate minor nesting sites of loggerhead turtles: $33=$ Calabria; $34=$ Sicilia; $35=$ Linosa; $36=$ Lampedusa; $37=$ Kuriat; $38=$ Chebba. Country abbreviations: $\mathrm{AL}=\mathrm{Alba}-$ nia; $\mathrm{BA}=$ Bosnia and Herzegovina $; \mathrm{EG}=$ Egypt $;$ GR = Greece; HR = Croatia; IL = Israel; IT = Italy; LB = Lebanon $;$ LY = Libya; $\mathrm{ME}=$ Montenegro $; \mathrm{SI}=$ Slovenia $; \mathrm{SY}=$ Syria $;$ $\mathrm{TN}=$ Tunisia $;$ TR $=$ Turkey. The eastern basin was divided into 5 arbitrary zones: Ad = Adriatic $; \mathrm{Ae}=$ Aegean; $\mathrm{L}=$ Levantine $; \mathrm{I}=$ Ionian; SCM = south-central Mediterranean

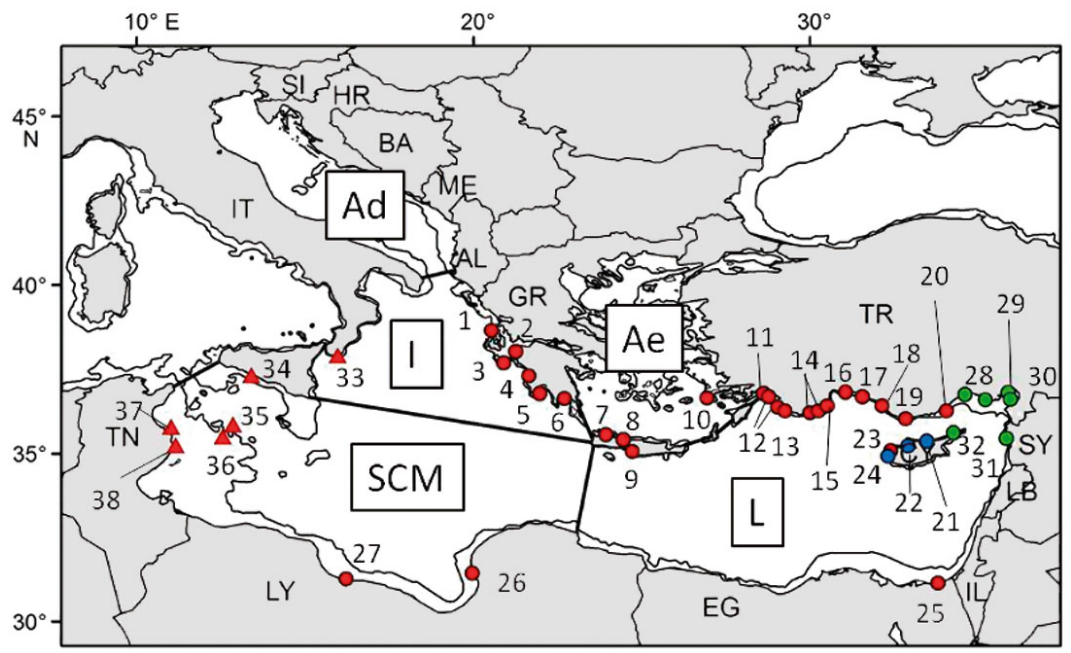

Table 1. Major nesting sites of loggerhead and green sea turtles in the Mediterranean with their average number of nests per year (Casale \& Margaritoulis 2010). As an optimization of the dispersal simulation, in certain cases 2 or more sites have been aggregated (as indicated by the symbol ' + ')

32 and 10 major sites (as defined by Casale \& Margaritoulis 2010) of loggerhead and green sea turtles, respectively, located in 5 countries (Cyprus, Egypt, Greece, Libya, Syria, Turkey), and 6 minor nesting sites of loggerhead turtles located in Italy (Calabria, Sicilia, Lampedusa, Linosa) (Mingozzi et al. 2007) and Tunisia (Kuriat, Chebba) (Casale \& Margaritoulis 2010) (Fig. 1). The latter sites may be of conservation interest in those countries, and they are the only nesting sites along the western coast of the eastern Mediterranean. Furthermore, some of these sites have been shown to be genetically distinct (Garofalo et al. 2009). A subset of the 32 major loggerhead sites and the 10 major green turtle sites were aggregated to optimize the dispersal simulations, resulting in 27 and 8 release sites of loggerhead and green sea turtles, respectively. Considering also the 6 minor sites of loggerheads, particles were released from a total of 33 loggerhead and 8 green turtle areas, all located in the eastern Mediterranean (Table 1, Fig. 1). Based on the average speed of loggerhead $\left(1.28 \mathrm{~km} \mathrm{~h}^{-1}\right)$ and green turtle hatchlings $\left(1.57 \mathrm{~km} \mathrm{~h}^{-1}\right)$ during the first $24 \mathrm{~h}$ in the sea (frenzy period) (Wyneken 1997), the particle release areas were centred ca. $30 \mathrm{~km}$ offshore from the nesting site. Release areas were ca. $20 \times$ $20 \mathrm{~km}$, except in 2 cases where smaller areas were adopted because of the coastline shape (e.g. gulfs).

The number of nests per year at each site $(N)$ ranges from a few nests to $>1000$ nests (Casale \&

\begin{tabular}{|c|c|c|}
\hline $\begin{array}{l}\text { Country/ } \\
\text { group }\end{array}$ & Site & $\begin{array}{l}\text { Avg. } \\
\text { nests } \mathrm{yr}^{-1}\end{array}$ \\
\hline \multicolumn{3}{|c|}{ Caretta caretta } \\
\hline Western & 1. Lefkas Island & 50 \\
\hline \multirow[t]{5}{*}{ Greece } & 2. Kotychi & 50 \\
\hline & 3. Zakynthos (Laganas Bay) & 1244 \\
\hline & 4. Kyparissia Bay & 685 \\
\hline & 5. Koroni & 50 \\
\hline & 6. Lakonikos Bay & 197 \\
\hline Eastern & 7. Bay of Chania & 94 \\
\hline \multirow[t]{3}{*}{ Greece } & 8. Rethymno & 324 \\
\hline & 9. Bay of Messara & 51 \\
\hline & 10. Kos Island & 60 \\
\hline \multirow[t]{10}{*}{ Turkey } & 11. Dalyan & 193.5 \\
\hline & 12. Dalaman + Fethiye & 222 \\
\hline & 13. Patara & 81 \\
\hline & 14. Kale + Finike-Kumluca & 264 \\
\hline & 15. Çıralı & 59.5 \\
\hline & 16. Belek & 443.5 \\
\hline & 17. Kizilot & 160 \\
\hline & 18. Demirtaş & 89 \\
\hline & 19. Anamur & 410 \\
\hline & 20. Göksu Delta & 93.5 \\
\hline \multirow[t]{4}{*}{ Cyprus } & 21. Alagadi & 123 \\
\hline & 22. Morphou Bay & 72 \\
\hline & 23. Chrysochou Bay & 100 \\
\hline & 24. Lara-Toxefra & 140 \\
\hline Egypt & 25. Areash & 67 \\
\hline \multirow[t]{2}{*}{ Libya } & 26. Al-Mteafla & 104 \\
\hline & $\begin{array}{l}\text { 27. Al- Ghbeba + Al-thalateen } \\
+ \text { Al-Arbaeen }\end{array}$ & 339 \\
\hline \multicolumn{3}{|c|}{ Chelonia mydas } \\
\hline \multirow[t]{3}{*}{ Turkey } & 28. Alata + Kazanlı + Akyatan & 768.5 \\
\hline & 29. Sugözü & 213 \\
\hline & 30. Samandağ & 230 \\
\hline Syria & 31. Latakia & 200 \\
\hline \multirow[t]{4}{*}{ Cyprus } & 32. North Karpaz & 104 \\
\hline & 21. Alagadi & 61 \\
\hline & 22. Morphou Bay & 42 \\
\hline & 24. Lara-Toxefra & 46 \\
\hline
\end{tabular}


Margaritoulis 2010), while the mean number of eggs per nest ranges from 65 to 130 (Margaritoulis et al. 2003). In the model, we defined the number of particles released at each site $\left(N_{p}\right)$ as being proportional to the number of nests per year $\left(N_{p}=N \times 100\right)$ to approximate the order of magnitude and the relative contribution of hatchlings from the different sites in the dispersion areas. These numbers do not consider interannual variability and embryo mortality (Margaritoulis et al. 2003) and are not meant to represent the exact number of hatchlings, which is not necessary in this kind of simulation (e.g. Hays et al. 2010). To capture dispersion patterns at minor sites, we arbitrarily set $N_{p}=1000$.

The hatching period in the Mediterranean occurs between the middle of July and the beginning of October, with the majority of turtle hatching occurring in August and September (Broderick \& Godley 1996, Margaritoulis 2005, Turkozan \& Yilmaz 2008). In the model, passive particles were released following a truncated Gaussian distribution in time, centered on 31 August with a standard deviation of $20 \mathrm{~d}$ and truncated at 1 August and 30 September. Trajectories were simulated using daily horizontal surface velocities (average at 0 to $3 \mathrm{~m}$ depth) extracted from the Mediterranean ocean forecasting system (Pinardi et al. 2003, Tonani et al. 2009) at $1 / 16^{\circ}$ resolution and linearly interpolated to the positions of the particles. Particle dynamics were governed by a first order equation of motion integrated forward in time with a Runge-Kutta second-order scheme, with time step of $1 \mathrm{~h}$. This particle-tracking algorithm replicates the dispersion processes of pelagic organisms in the Mediterranean Sea (Hays et al. 2010, Mariani et al. 2010), with further development to allow for continuous particle release in this study.

All simulations were run until 1 February (transport of 125 to 185 d), i.e. 4 to 6 mo after release. Loggerheads of about 6 mo in age have a CCL of about $10 \mathrm{~cm}$ length (Casale et al. 2009a), and it is likely that passive drift is no longer the only form of movement; hence particle tracking may be less useful to infer dispersal at this point. However, other studies carried out passive drifting simulations for $1 \mathrm{yr}$ or more (e.g. Putman et al. 2012). In order to provide further insights on the effect of prolonged dispersal by drifting in loggerheads, and especially on potential distribution of loggerheads in the western Mediterranean, we extended the simulation of particles from loggerhead nesting sites until 26 July and 31 December of the next year. Simulations were repeated for 5 separate years (2001 through 2005), to account for the variability in ocean conditions. The simulated hatch- ling distributions were then analyzed at 1 December (same year of release), 1 February, 26 July and 31 December (next year); the latter 2 only for loggerheads, excluding any particles that hit land. Distributions from different years were pooled together and analyzed in ArcGIS 10.0. The eastern Mediterranean basin was arbitrarily divided into 5 zones: Adriatic, Aegean, Levantine, Ionian, and South-central Mediterranean (Fig. 1). The number of particles from each major release area which occurred in each marine zone on 1 February was used to calculate (1) the proportions of particles found in a specific marine zone and originating from different release sites, simulating the different origin of turtles found in a common foraging zone, and (2) the proportions of particles from a specific release site that dispersed to different marine zones, simulating the relative importance of different foraging zones for a specific nesting site.

\section{RESULTS}

A total of 3745250 particles were released in the simulation, and the resulting dispersal patterns for each of the 41 release areas are shown in the Supplement at www.int-res.com/articles/suppl/m498p263_ supp.pdf: Figs. S1 to S9 (loggerhead turtles), and Figs. S10 \& S11 (green turtles) show dispersal on 1 December; Figs. S12 to S20 (loggerhead turtles) and Figs. S21 \& S22 (green turtles) show dispersal on 1 February. In several cases, particles released at the major nesting areas had similar dispersal patterns and were aggregated into 5 groups for loggerhead turtle nesting areas (Western Greece, Eastern Greece, Turkey, Cyprus, Libya) and 3 groups for green turtle nesting areas (Turkey, Cyprus, Syria) (1 Dec, Fig. S23; 1 Feb, Fig. 2).

By 1 December, particles had already reached all the marine zones where they occurred on 1 February, and the most evident difference was the further dispersal to the Levantine marine zone by particles released in Greece and Libya (Figs. S23 \& S24, Figs. $2 \& 3$, Table 2). Density distributions (Fig. 3) highlight 4 major distribution patterns for loggerhead nesting sites: (1) Ionian/Adriatic by particles from western Greece, (2) Levantine/Ionian by particles from eastern Greece, (3) Levantine by particles from Turkey and Cyprus, and (4) south-central Mediterranean by particles from Libya. All green turtle nesting areas (Turkey, Cyprus and Syria) showed pattern (3) (Levantine). Particle counts (Table 2) indicate that the Levantine marine zone hosted the greatest proportion of particles from all green turtle 

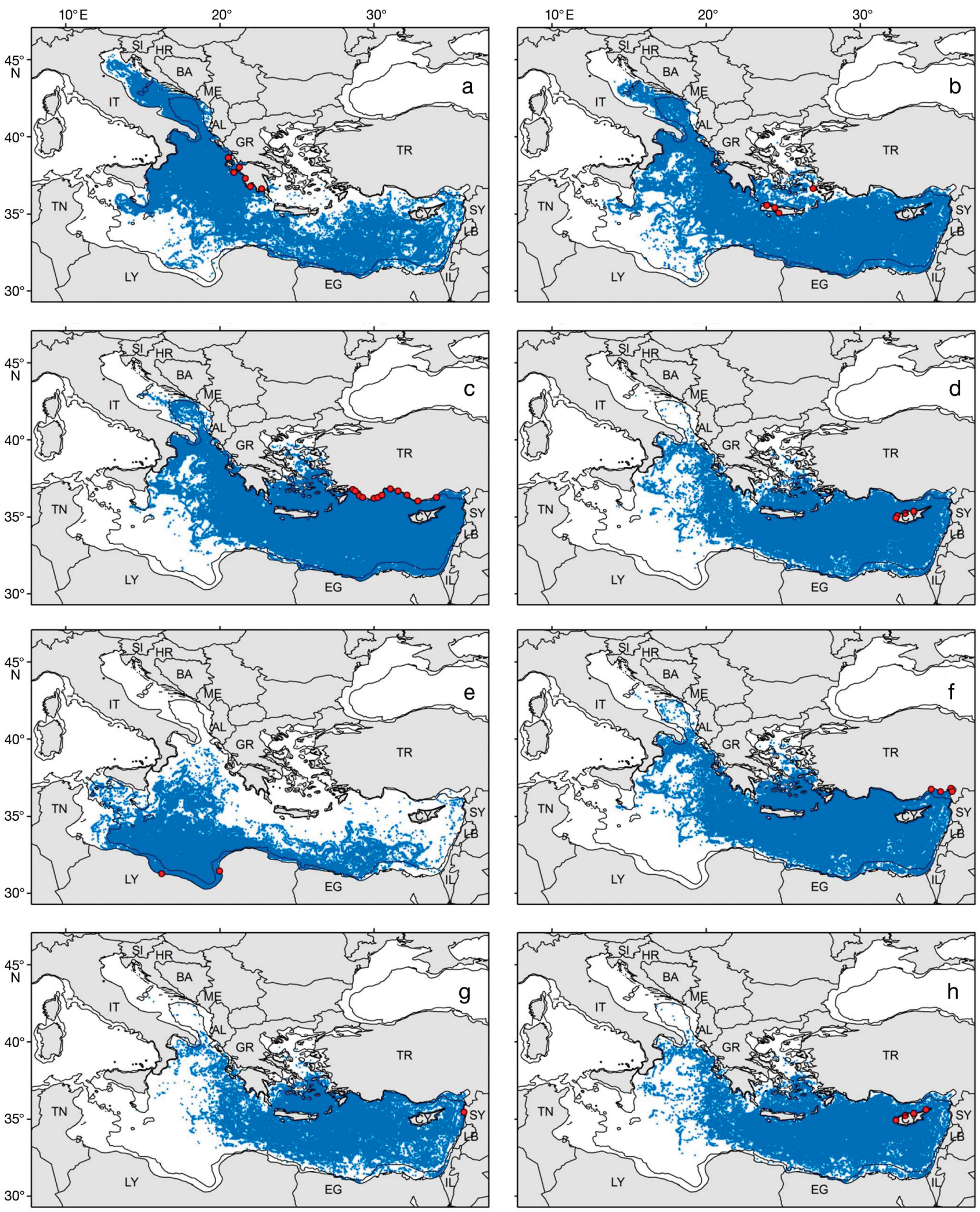

Fig. 2. Position on February 1 of particles released in August-September at Mediterranean nesting areas of (a-e) loggerhead and (f-h) green turtles: (a) western Greece; (b) eastern Greece; (c,f) Turkey; (d,h) Cyprus; (e) Libya; and (g) Syria. Circles indicate nesting sites as shown in Fig. 1; codes and symbols as in Fig. 1 
areas and from loggerhead turtle areas in eastern Greece, Turkey, Cyprus, and Egypt, while the southcentral and Ionian zones were the most important zones for nesting areas in Libya and Western Greece, respectively. At the species level, by 1 February, particles from loggerhead turtle nesting areas had dispersed throughout the eastern Mediterranean basin, with high density areas in all the marine zones (Fig. 4) and the highest proportion of particles occurring in the Levantine zone (Table 2). No particles dispersed into the western Mediterranean, with the only exception being the minor nesting areas in Tunisia (Fig. S20). By 1 February, particles from green turtle nesting areas were mainly dispersed in the Levantine and Ionian zones, and to a lesser extent in the other 3 zones, with the majority of high density areas (Fig. 4) and the highest proportion of particles (Table 2) occurring in the Levantine marine zone. The distribution of particles from loggerhead nesting sites obtained by the extended simulation until 26 July and 31 December of the next year was not different from the shorter simulations (Figs. S25 \& S26).

Regarding the mixed origin of the pool of particles at a specific marine zone; for loggerhead turtles, western Greece was the major contributor to the Adriatic and Ionian zones, while Turkey was the major contributor to Aegean and Levantine zones, and Libya to the south-central zone (Table 3). For green turtle areas, Turkey was the major contributor to all zones (Table 3 ).

\section{DISCUSSION}

\section{The first 'lost year' of Mediterranean sea turtles}

To infer hatchling dispersal patterns of Mediterranean sea turtles, we expand on previous work that used a single nesting site (Zakynthos island, Greece; Hays et al. 2010), by applying particle drift trajectories to 38 loggerhead and 10 green turtle nesting sites in the Mediterranean. The results indicate that hatchlings from the Levantine and south-central zones are mainly retained in the same zone of origin, while those from the Ionian zone disperse mainly to the Ionian, Adriatic, and south-central zones. This general dispersal pattern, which is associated with coastal areas, potentially provides insights into the location of hatchling turtles from specific known or as yet undiscovered nesting sites. For instance, new nesting sites have recently been discovered (Rees et al. 2008) even in highly developed areas (Mingozzi et al. 2007), and other nesting sites may be discovered in the future, e.g. in Libya (Casale \& Margaritoulis 2010). This information

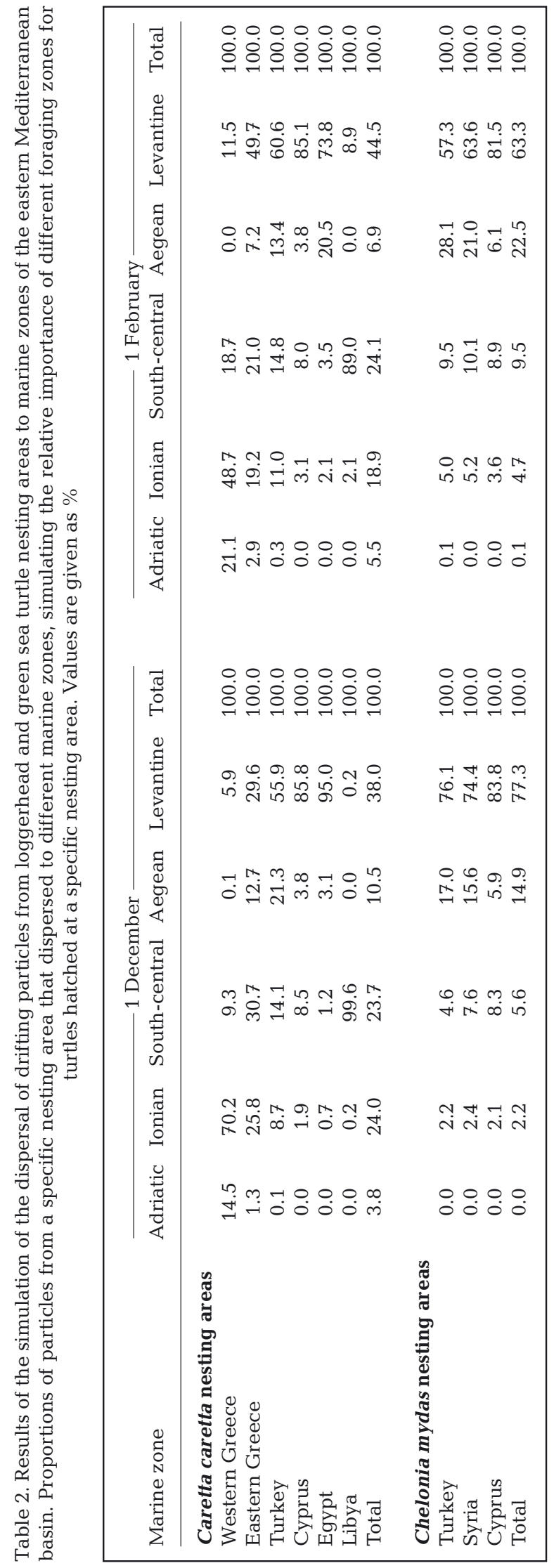



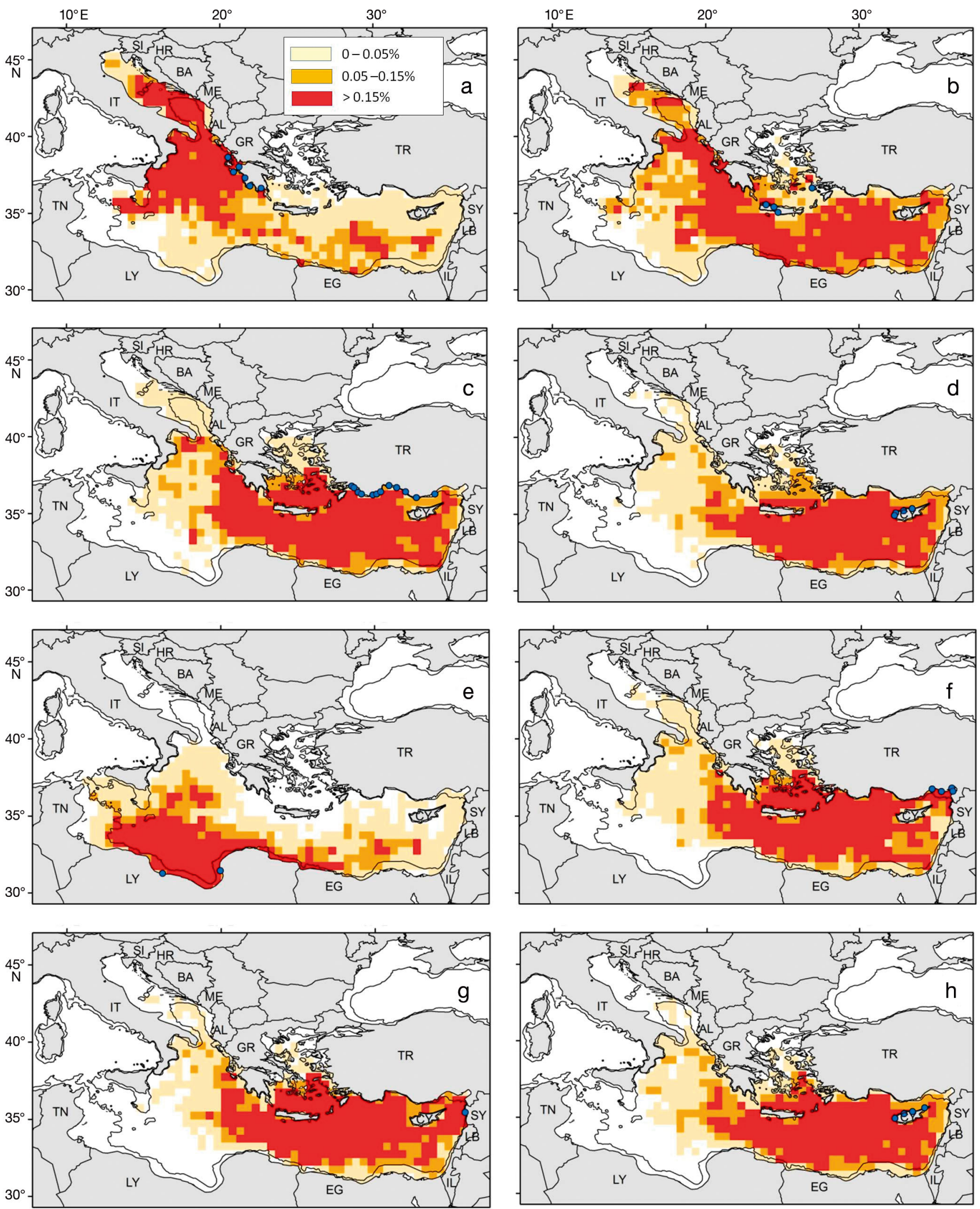

Fig. 3. Relative density on February 1 of particles released in August-September at Mediterranean nesting areas of (a-e) loggerhead and (f-h) green turtles: (a) western Greece; (b) eastern Greece; (c,f) Turkey; (d,h) Cyprus; (e) Libya; and (g) Syria. Circles indicate nesting sites as shown in Fig. 1; codes and symbols as in Fig. 1 

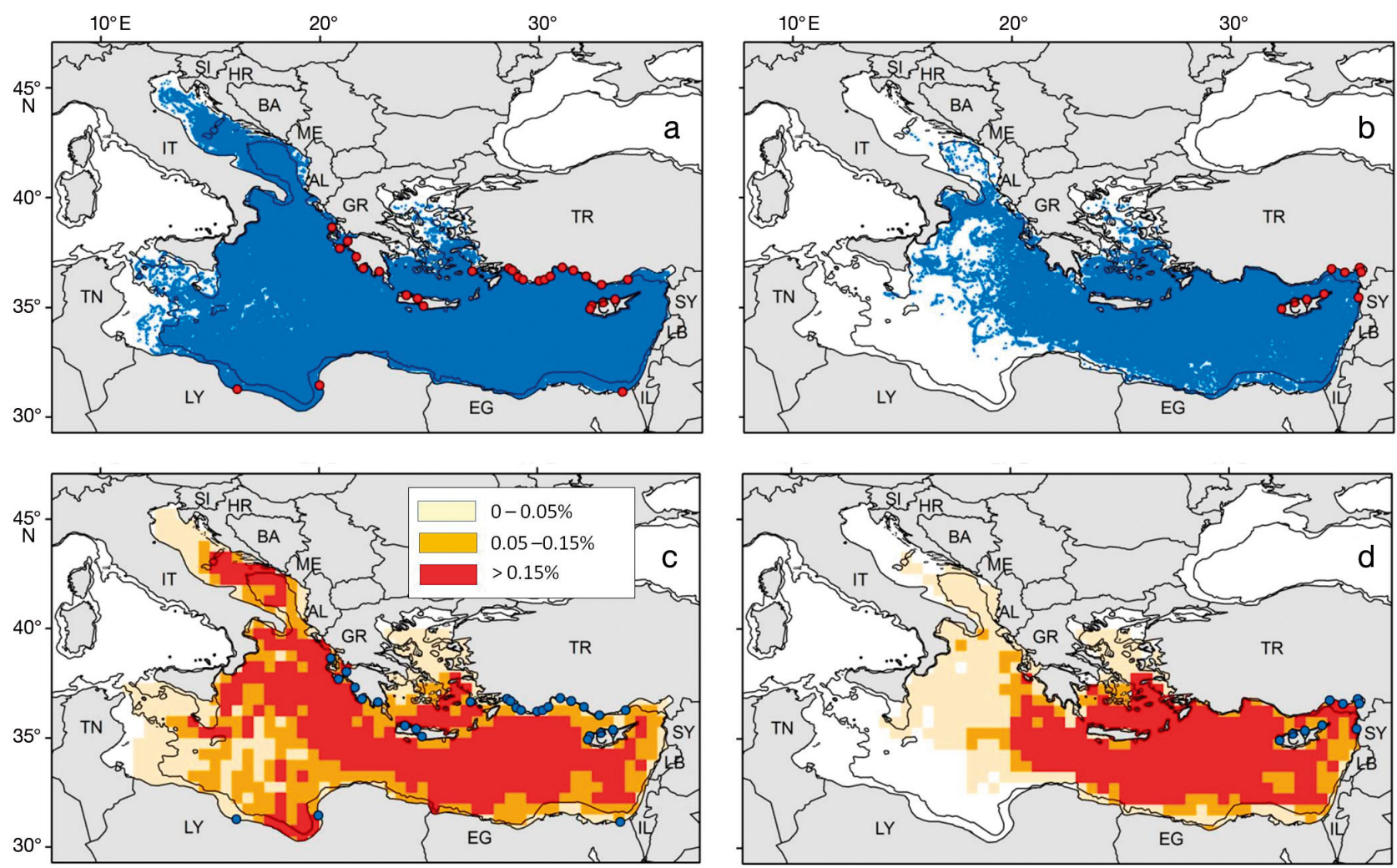

Fig. 4. $(\mathrm{a}, \mathrm{b})$ Position and $(\mathrm{c}, \mathrm{d})$ relative density in February of particles released in August-September at Mediterranean nesting areas of $(\mathrm{a}, \mathrm{c})$ loggerhead and $(\mathrm{b}, \mathrm{d})$ green turtles. Circles indicate nesting sites as shown in Fig. 1; codes and symbols as in Fig. 1

regarding potential hatchling dispersal may be of interest when drafting conservation plans at regional or national levels.

Our results indicate that the Levantine zone is a nursery zone for Mediterranean sea turtles. Indeed, most green turtle hatchlings and about half of loggerhead hatchlings likely aggregate in the Levantine zone at least in their first 6 mo of life. The second important area for loggerhead hatchlings appears to be the Ionian-south Adriatic. Accordingly, turtles of the size range $(<10 \mathrm{~cm})$, corresponding approximately to the age range considered in this study $(<6 \mathrm{mo}$; Casale et al. 2009a), have been found stranded along the Ionian-south Adriatic coasts of Italy (Casale et

Table 3. Results of the simulation of the dispersal of drifting particles from loggerhead and green sea turtle nesting areas to marine zones of the eastern Mediterranean basin. Proportions of particles found in a specific marine zone originated from different nesting areas, simulating the different origin of turtles found in a common foraging zone. Values are given as \%

\begin{tabular}{|c|c|c|c|c|c|c|c|c|c|c|}
\hline Marine zone & Adriatic & Ionian & $\begin{array}{l}1 \text { December } \\
\text { South-Central }\end{array}$ & Aegean & Levantine & Adriatic & Ionian & $\begin{array}{l}1 \text { February } \\
\text { South-Central }\end{array}$ & Aegean & Levantine \\
\hline \multicolumn{11}{|c|}{ Caretta caretta nesting areas } \\
\hline Western Greece & 95.7 & 72.9 & 9.8 & 0.1 & 3.9 & 92.7 & 62.6 & 18.9 & 0.1 & 6.3 \\
\hline Eastern Greece & 3.5 & 11.3 & 13.7 & 12.8 & 8.2 & 5.3 & 10.2 & 8.8 & 10.5 & 11.3 \\
\hline Turkey & 0.8 & 14.8 & 24.3 & 82.7 & 60.0 & 2.0 & 23.8 & 25.2 & 79.6 & 56.0 \\
\hline Cyprus & 0.0 & 0.9 & 3.9 & 3.9 & 24.2 & 0.0 & 1.9 & 3.8 & 6.3 & 22.2 \\
\hline Egypt & 0.0 & 0.0 & 0.1 & 0.4 & 3.6 & 0.0 & 0.1 & 0.2 & 3.5 & 2.0 \\
\hline Libya & 0.0 & 0.1 & 48.2 & 0.0 & 0.1 & 0.0 & 1.3 & 43.0 & 0.0 & 2.3 \\
\hline Total & 100.0 & 100.0 & 100.0 & 100.0 & 100.0 & 100.0 & 100.0 & 100.0 & 100.0 & 100.0 \\
\hline \multicolumn{11}{|c|}{ Chelonia mydas nesting areas } \\
\hline Turkey & 88.5 & 71.1 & 58.8 & 81.3 & 70.1 & 83.2 & 70.4 & 66.6 & 82.7 & 59.9 \\
\hline Syria & 11.5 & 12.4 & 15.3 & 11.8 & 10.9 & 11.2 & 13.4 & 13.1 & 11.5 & 12.4 \\
\hline Cyprus & 0.0 & 16.4 & 25.9 & 6.9 & 19.0 & 5.6 & 16.2 & 20.3 & 5.8 & 27.7 \\
\hline Total & 100.0 & 100.0 & 100.0 & 100.0 & 100.0 & 100.0 & 100.0 & 100.0 & 100.0 & 100.0 \\
\hline
\end{tabular}


al. 2010). Unfortunately, no size data of stranding turtles are available from the Ionian coast of Greece at present, where stranded hatchling are expected on the basis of simulated particles hitting land.

Our results also suggest that turtles are not transported by currents into the western basin during their first 6 mo of life. This is coherent with the low number (only 1 individual) of stranded turtles $<10 \mathrm{~cm}$ CCL - the approximate size of loggerhead turtles at 6 mo of age (Casale et al. 2009a) - reported from the western side of Italy in contrast to the eastern side (Casale et al. 2010).

\section{Comparison with empirical data on the distribution of older life stages}

There is a long time gap between the life period simulated in this study (first 6 mo of life) and when turtles are commonly observed by empirical means (>40 cm CCL). For loggerhead turtles, this period is several years in duration: on the basis of available age-size curves for loggerheads in the Mediterranean, turtles $>40 \mathrm{~cm}$ CCL are probably older than $7 \mathrm{yr}$ (Casale et al. 2009b, 2011a,b). Age-size curves of Mediterranean green turtles are not available; however, curves from the Atlantic indicate a similar age, i.e. green turtles $>40 \mathrm{~cm}$ CCL are probably older than 8 yr (Goshe et al. 2010).

Limited empirical observations suggest that, at least in some zones, turtles tend to remain for several months in the same zone to which they dispersed as hatchlings. In particular, available reports of high proportions of small loggerheads in the Ionian-south Adriatic (<30 cm CCL; Casale et al. 2010) and small green turtles in the Levantine zone (Turkey; $<30 \mathrm{~cm}$ CCL; Türkozan et al. 2013) are coherent with the hatchling dispersal simulated by the present study. Moreover, the present results on loggerhead hatchling dispersal are quite similar to empirical data on large juveniles (>40 cm CCL) and adults for those zones where data are available. For instance, our results on hatchling dispersal as well as genetic data (Garofalo et al. 2013), tagging (Margaritoulis et al. 2003), and satellite tracking data (Casale et al. 2013, Schofield et al. 2013) indicate Libya and Greece as major contributors to the south-central zone, and Greece as the major contributor to the Adriatic zone. These observations also indicate that a number of turtles from Turkey frequent the Ionian and the Adriatic zones.

Our results suggest a low hatchling dispersal from the eastern into the western basin of the Mediterranean Sea. On the basis of genetic markers, Carreras et al. (2006) proposed that loggerheads originating from the eastern Mediterranean and entering the western basin follow the main surface currents and disperse in the Tyrrhenian Sea along the Italian coast, and then along the coasts of France and Spain. Recent genetic data from the Tyrrhenian Sea support this hypothesis (Maffucci et al. 2013). Four different types of empirical data indicate a relatively low turtle occurrence in the Tyrrhenian Sea. First, only $2 \%$ of tag returns (Margaritoulis et al. 2003) and $1.4 \%$ of turtles satellite tracked (Schofield et al. 2013) from western Greece nesting sites were observed in the western Mediterranean, suggesting that this area is frequented by a minority of adults with eastern Mediterranean origin. Second, a lower stranding turtle density (which, however, may be affected by several factors, including currents) was observed in the north $\left(0.05\right.$ turtles $\left.\mathrm{km}^{-1}\right)$ and south Tyrrhenian Sea (0.11 turtles $\left.\mathrm{km}^{-1}\right)$, than in the eastern Mediterranean, and specifically in the Sicily Channel (0.30 turtles $\mathrm{km}^{-1}$ ) and the Ionian Sea (0.31 turtles $\mathrm{km}^{-1}$ ) (Casale et al. 2010). Third, the observed turtle catch rates from longliners targeting swordfish were lower in the north Tyrrhenian (0.00062 turtles hooks ${ }^{-3}$ ) (Orsi Relini et al. 1999) than in the Sicily Channel (0.977 turtles hooks ${ }^{-3}$ ) (Casale et al. 2007a) and in the Ionian Sea (0.269 to 2.76 turtles hooks ${ }^{-3}$ ) (Deflorio et al. 2005, Cambiè et al. 2010). Finally, aerial surveys indicate a lower turtle density during summer in the north Tyrrhenian (0.046 turtles $\mathrm{km}^{-2}$ ) (Lauriano et al. 2011) than in the westernmost part of the basin $(0.21$ turtles $\mathrm{km}^{-2}$ ) (Gomez de Segura et al. 2006), mainly frequented by loggerhead turtles from the Atlantic (Carreras et al. 2006). Moreover, observations of the surface currents using Lagrangian drifters (Poulain \& Zambianchi 2007) show that a persistent southeastward circulation is present in the Sicily Channel throughout the year. On this basis, we hypothesize that hatchling dispersal pattern and the prevalent eastward surface current at the Sicily Channel may explain, at least in part, the lower turtle occurrence observed thus far in the Tyrrhenian Sea. We additionally hypothesize that those loggerheads moving from the eastern to the western Mediterranean do so by active swimming. In this respect, the low proportion of small loggerhead turtles $(<30 \mathrm{~cm}$ CCL) stranded along the western side of Italy (Casale et al. 2010) suggests that loggerhead turtles move into the western basin at a size when they have attained good swimming skills. A similar pattern was suggested for the Strait of Gibraltar (Revelles et al. 2007a), another strait where prevalent surface currents run in one direction. 
The present hatchling dispersal simulation is also coherent with the available empirical data on the distribution of green turtles, which are mainly found in the Levantine zone (Casale \& Margaritoulis 2010, Oruç et al. 2011, Türkozan et al. 2013). Green turtles are also reported from the Aegean and Ionian (south Peloponnesus, Greece), while in the south-central zone juveniles and adults frequent Libyan, and to a lesser extent Tunisian waters (Broderick et al. 2007, Casale \& Margaritoulis 2010, Turkecan \& Yerli 2011). Naturally, as they grow, green turtles increasingly feed upon benthic seagrasses and algae until they become fully herbivorous at a size $>62 \mathrm{~cm}$ CCL in the Mediterranean (Cardona et al. 2010). This may affect their habitat requirements and may result in a distribution and fidelity to foraging areas different from loggerhead turtles (e.g. Broderick et al. 2007).

Notwithstanding the significant knowledge gaps about turtle distribution, especially during the several years between the early-life period simulated in this study and that observed by empirical studies (see above), the similarity of the results provided by this and other studies is intriguing. We hypothesize that the distribution of hatchlings affects, at least to a certain extent, the future distribution of juveniles, and in turn of adults. This would not exclude that some individuals frequent distant areas for a period of their life and that some individuals even settle there permanently. Similarly, previous studies in the Mediterranean hypothesized that hatchling dispersal from Zakynthos island (Greece) determines the adult foraging zones of this population (Hays et al. 2010), and that large juveniles settle in neritic zones close to the oceanic zones they frequented as small juveniles (Casale et al. 2007b).

\section{A model of the dispersal and distribution of Mediterranean sea turtles}

Combining our simulations with existing empirical information, we propose a general distribution model between nesting sites, and oceanic and neritic foraging areas for Mediterranean sea turtles (Fig. 5), which extends a previous model (Casale et al. 2007b). The main model prediction to be tested by future empirical studies (e.g. aerial surveys, by-catch, stranding surveys, satellite-tracking, capture-mark-recapture, genetic markers) is a high proportion of turtles frequenting a marine area within the same geographic zone of their natal nesting site, with the exception of the western Greece nesting area. Specifically, the Levantine zone is expected to be frequented mainly by turtles originating from the same region, in particular from Turkey and Cyprus, and vice-versa. The south-central Mediterranean zone is expected to be frequented mainly by turtles originating from the same region, in particular Libya, and vice-versa. In contrast, turtles from the Ionian zone (Greece) would disperse both in this zone and in other zones. While the Adriatic zone is expected to be frequented almost exclusively by turtles from Greece, the Ionian is expected to be frequented by turtles originating from most of the rookeries and zones. If confirmed, such a dispersal pattern would
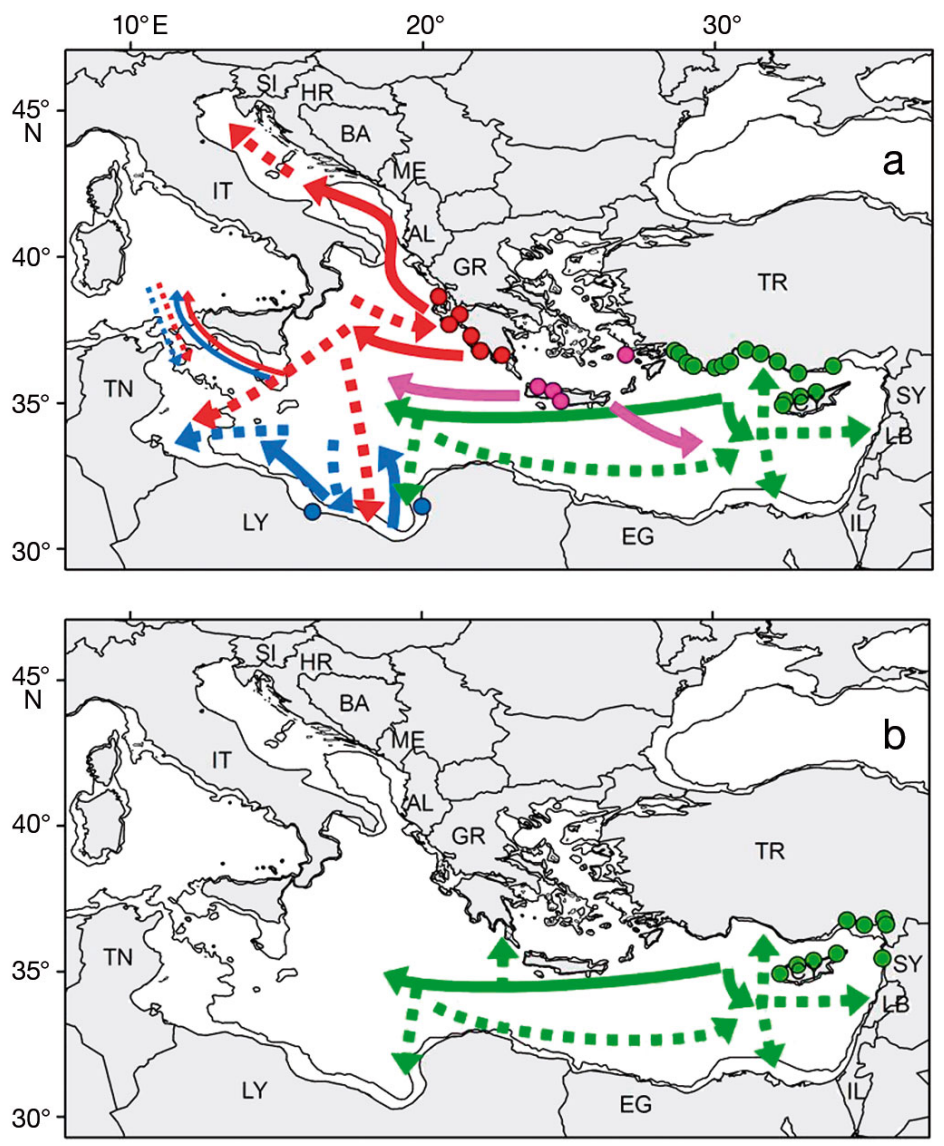

Fig. 5. Caretta caretta and Chelonia mydas. Model of distribution pattern for (a) loggerhead and (b) green turtles in the eastern Mediterranean. Circles indicate nesting sites (see Fig. 1). Solid arrows indicate main hatchling dispersal and possible oceanic habitats for small juveniles; dashed arrows indicate main connection between oceanic and neritic habitats where turtles would eventually settle. Arrows of different colours represent dispersal of turtles from groups of nesting sites of the same colour; arrows represent connections between areas and are not meant to represent migratory routes. Only connections between major foraging areas are shown. Codes and symbols as in Fig. 1 
reduce the need for a pan-Mediterranean conservation approach, and would allow the identification of subregional management units for conservation, similar to the proposal of Lazar et al. (2004) for the Ionian-Adriatic zone. Under this approach, a management unit would comprise the foraging areas frequented by most turtles from a specific nesting area (e.g. Schofield et al. 2013). Relatively few of the many Mediterranean countries would be responsible for the conservation of such subregional management units, except the western Greece loggerhead population (Schofield et al. 2013). Examples might be: (1) the Libyan unit managed by Libya and Tunisia, (2) the Levantine unit, managed by Turkey, Cyprus, Egypt, and Libya, (3) the Greek unit, managed by Greece, Italy, Croatia, Tunisia, and possibly Albania and Libya. In-water studies with multiple approaches in the Levantine and south-central zones are a research priority for verifying this hypothesis that, if confirmed, may facilitate turtle conservation in the Mediterranean through a relatively small-scale international approach.

Acknowledgements. P.M. was supported by the EU project 'Towards COast to COast NETworks of marine protected areas (from the shore to the high and deep sea), coupled with sea-based wind energy potential' (COCONET, EU FP7 No. 287844). We thank 3 anonymous reviewers for their valuable comments and M. R. Payne, DTU Aqua, for English revision.

\section{LITERATURE CITED}

Bentivegna F, Valentino F, Falco P, Zambianchi E, Hochscheid S (2007) The relationship between loggerhead turtle (Caretta caretta) movement patterns and Mediterranean currents. Mar Biol 151:1605-1614

Bjorndal KA (1997) Foraging ecology and nutrition of sea turtles. In: Lutz PL, Musick JA (eds) The biology of sea turtles. CRC Marine Science Series, CRC Press, Boca Raton, FL, p 199-231

Broderick AC, Godley BJ (1996) Population and nesting ecology of the green turtle, Chelonia mydas, and the loggerhead turtle, Caretta caretta, in northern Cyprus. Zool Middle East 13:27-46

Broderick AC, Coyne MS, Fuller WJ, Glen F, Godley BJ (2007) Fidelity and over-wintering of sea turtles. Proc R Soc B 274:1533-1538

Cambiè G, Caminas JA, Franquesa R, Mingozzi T (2010) Fishing activity and impacts along the main nesting area of loggerhead sea turtle Caretta caretta in Italy: overwhelming discrepancy with the official data. Sci Mar 74: 275-285

Cardona L, Campos P, Levy Y, Demetropoulos A, Margaritoulis D (2010) Asynchrony between dietary and nutritional shifts during the ontogeny of green turtles (Chelonia mydas) in the Mediterranean. J Exp Mar Biol Ecol 393:83-89

Carr A, Meylan AB (1980) Evidence of passive migration of green turtle hatchlings in sargassum. Copeia 1980: 366-368
Carreras C, Pont S, Maffucci F, Pascual M and others (2006) Genetic structuring of immature loggerhead sea turtles (Caretta caretta) in the Mediterranean Sea reflects water circulation patterns. Mar Biol 149:1269-1279

> Casale P (2011) Sea turtle by-catch in the Mediterranean. Fish Fish 12:299-316

Casale P, Margaritoulis D (2010) Sea turtles in the Mediterranean: distribution, threats and conservation priorities. IUCN, Gland

> Casale P, Cattarino L, Freggi D, Rocco M, Argano R (2007a) Incidental catch of marine turtles by Italian trawlers and longliners in the central Mediterranean. Aquat Conserv 17:686-701

> Casale P, Freggi D, Basso R, Vallini C, Argano R (2007b) A model of area fidelity, nomadism, and distribution patterns of loggerhead sea turtles (Caretta caretta) in the Mediterranean Sea. Mar Biol 152:1039-1049

Casale P, Mazaris AD, Freggi D, Basso R, Argano R (2007c) Survival probabilities of loggerhead sea turtles (Caretta caretta) estimated from capture-mark-recapture data in the Mediterranean Sea. Sci Mar 71:365-372

Casale P, d'Astore PP, Argano R (2009a) Age at size and growth rates of early juvenile loggerhead sea turtles (Caretta caretta) in the Mediterranean based on length frequency analysis. Herpetol J 19:29-33

Casale P, Mazaris AD, Freggi D, Vallini C, Argano R (2009b) Growth rates and age at adult size of loggerhead sea turtles (Caretta caretta) in the Mediterranean Sea, estimated through capture-mark-recapture records. Sci Mar 73:589-595

Casale P, Affronte M, Insacco G, Freggi D and others (2010) Sea turtle strandings reveal high anthropogenic mortality in Italian waters. Aquat Conserv 20:611-620

Casale P, Conte N, Freggi D, Cioni C, Argano R (2011a) Age and growth determination by skeletochronology in loggerhead sea turtles (Caretta caretta) from the Mediterranean Sea. Sci Mar 75:197-203

> Casale P, Mazaris AD, Freggi D (2011b) Estimation of age at maturity of loggerhead sea turtles Caretta caretta in the Mediterranean using length-frequency data. Endang Species Res 13:123-129

> Casale P, Freggi D, Cinà A, Rocco M (2013) Spatio-temporal distribution and migration of adult male loggerhead sea turtles (Caretta caretta) in the Mediterranean Sea: further evidence of the importance of neritic habitats off North Africa. Mar Biol 160:703-718

Deflorio M, Aprea A, Corriero A, Santamaria N, De Metrio G (2005) Incidental captures of sea turtles by swordfish and albacore longlines in the Ionian sea. Fish Sci 71:1010-1018

> Garofalo L, Mingozzi T, Mico A, Novelletto A (2009) Loggerhead turtle (Caretta caretta) matrilines in the Mediterranean: further evidence of genetic diversity and connectivity. Mar Biol 156:2085-2095

Garofalo L, Mastrogiacomo A, Casale P, Carlini R and others (2013) Genetic characterization of central Mediterranean stocks of the loggerhead turtle (Caretta caretta) using mitochondrial and nuclear markers, and conservation implications. Aquat Conserv 23:868-884

Gomez de Segura A, Tomas J, Pedraza SN, Crespo EA, Raga JA (2006) Abundance and distribution of the endangered loggerhead turtle in Spanish Mediterranean waters and the conservation implications. Anim Conserv 9:199-206

Goshe LR, Avens L, Scharf FS, Southwood AL (2010) Estimation of age at maturation and growth of Atlantic green turtles (Chelonia mydas) using skeletochronology. Mar 
Biol 157:1725-1740

> Hays GC, Fossette S, Katselidis KA, Mariani P, Schofield G (2010) Ontogenetic development of migration: Lagrangian drift trajectories suggest a new paradigm for sea turtles. J R Soc Interface 7:1319-1327

Lambardi P, Lutjeharms JRE, Mencacci R, Hays GC, Luschi $P$ (2008) Influence of ocean currents on long-distance movement of leatherback sea turtles in the Southwest Indian Ocean. Mar Ecol Prog Ser 353:289-301

Lauriano G, Panigada S, Casale P, Pierantonio N, Donovan G (2011) Aerial survey abundance estimates of the loggerhead sea turtle Caretta caretta in the Pelagos Sanctuary, northwestern Mediterranean Sea. Mar Ecol Prog Ser 437:291-302

> Lazar B, Margaritoulis D, Tvrtkovic N (2004) Tag recoveries of the loggerhead sea turtle Caretta caretta in the eastern Adriatic Sea: implications for conservation. J Mar Biol Assoc UK 84:475-480

Maffucci F, D'Angelo I, Hochscheid S, Ciampa M and others (2013) Sex ratio of juvenile loggerhead turtles in the Mediterranean Sea: Is it really 1:1? Mar Biol 160:1097-1107

Margaritoulis D (2005) Nesting activity and reproductive output of loggerhead sea turtles, Caretta caretta, over 19 seasons (1984-2002) at Laganas Bay, Zakynthos, Greece: the largest rookery in the Mediterranean. Chelonian Conserv Biol 4:916-929

Margaritoulis D, Argano R, Baran I, Bentivegna F and others (2003) Loggerhead turtles in the Mediterranean Sea: present knowledge and conservation perspectives. In: Bolten $\mathrm{AB}$, Witherington $\mathrm{B}$ (eds) Biology and conservation of loggerhead sea turtles. Smithsonian Institution Press, Washington, DC, p 175-198

> Mariani P, MacKenzie BR, Iudicone D, Bozec A (2010) Modelling retention and dispersion mechanisms of bluefin tuna eggs and larvae in the northwest Mediterranean Sea. Prog Oceanogr 86:45-58

Milsom WK (1975) Development of buoyancy control in juvenile Atlantic loggerhead turtles, Caretta c. caretta. Copeia 1975:758-762

Mingozzi T, Masciari G, Paolillo G, Pisani B, Russo M, Massolo A (2007) Discovery of a regular nesting area of loggerhead turtle Caretta caretta in southern Italy: a new perspective for national conservation. Biodivers Conserv 16:3519-3541

Monzón-Argüello C, López-Jurado LF, Rico C, Marco A, López P, Hays GC, Lee PLM (2010) Evidence from genetic and Lagrangian drifter data for transatlantic transport of small juvenile green turtles. J Biogeogr 37: 1752-1766

Nichols WJ, Resendiz A, Seminoff JA, Resendiz B (2000) Transpacific migration of a loggerhead turtle monitored by satellite telemetry. Bull Mar Sci 67:937-947

Okuyama J, Kitagawa T, Zenimoto K, Kimura S, Arai N, Sasai Y, Sasaki H (2011) Trans-Pacific dispersal of loggerhead turtle hatchlings inferred from numerical simulation modeling. Mar Biol 158:2055-2063

Orsi Relini L, Palandri G, Garibaldi F, Cima C (1999) Longline swordfish fishery in the Ligurian Sea: eight years of observation on target and bycatch species. Collect Vol Sci Pap ICCAT 49:146-150

Oruç A, Tural U, Cesur T (2011) A review of potential marine habitats for marine turtles in Turkey. Mar Turtle Newsl 131:23-25

Pinardi N, Allen I, Demirov E, De Mey P and others (2003) The Mediterranean ocean forecasting system: first phase of implementation (1998-2001). Ann Geophys 21:3-20

Poulain PM, Zambianchi E (2007) Surface circulation in the central Mediterranean Sea as deduced from Lagrangian drifters in the 1990s. Cont Shelf Res 27:981-1001

> Putman NF, Scott R, Verley P, Marsh R, Hays GC (2012) Natal site and offshore swimming influence fitness and long-distance ocean transport in young sea turtles. Mar Biol 159:2117-2126

> Rees AF, Saad A, Jony M (2008) Discovery of a regionally important green turtle Chelonia mydas rookery in Syria. Oryx 42:456-459

> Revelles M, Carreras C, Cardona L, Marco A and others (2007a) Evidence for an asymmetrical size exchange of loggerhead sea turtles between the Mediterranean and the Atlantic through the Straits of Gibraltar. J Exp Mar Biol Ecol 349:261-271

> Revelles M, Isem-Fontanet J, Cardona L, Felix MS, Carreras C, Aguilar A (2007b) Mesoscale eddies, surface circulation and the scale of habitat selection by immature loggerhead sea turtles. J Exp Mar Biol Ecol 347:41-57

Revelles M, Caminas JA, Cardona L, Parga M and others (2008) Tagging reveals limited exchange of immature loggerhead sea turtles (Caretta caretta) between regions in the western Mediterranean. Sci Mar 72:511-518

Schofield G, Dimadi A, Fossette S, Katselidis KA and others (2013) Satellite tracking large numbers of individuals to infer population level dispersal and core areas for the protection of an endangered species. Divers Distrib 19: 834-844

Shillinger GL, Di Lorenzo E, Luo H, Bograd SJ, Hazen EL, Bailey H, Spotila JR (2012) On the dispersal of leatherback turtle hatchlings from Mesoamerican nesting beaches. Proc R Soc B 279:2391-2395

Tomás J, Gozalbes P, Raga JA, Godley BJ (2008) Bycatch of loggerhead sea turtles: insights from 14 years of stranding data. Endang Species Res 5:161-169

Tonani M, Pinardi N, Fratianni C, Pistoia J and others (2009) Mediterranean Forecasting System: forecast and analysis assessment through skill scores. Ocean Sci 5:649-660

Turkecan O, Yerli SV (2011) Satellite tracking of adult green sea turtles from Turkey: a long distance diary. Mar Turtle Newsl 131:38-41

> Turkozan O, Yilmaz C (2008) Loggerhead turtles, Caretta caretta, at Dalyan Beach, Turkey: nesting activity (20042005) and 19-year abundance trend (1987-2005). Chelonian Conserv Biol 7:178-187

Türkozan O, Özdilek SY, Ergene S, Uçar AH and others (2013) Strandings of loggerhead (Caretta caretta) and green (Chelonia mydas) sea turtles along the eastern Mediterranean coast of Turkey. Herpetol J 23:11-15

Wallace BP, DiMatteo AD, Bolten AB, Chaloupka MY and others (2011) Global conservation priorities for marine turtles. PLoS ONE 6:e24510

Witherington B, Hirama S, Hardy R (2012) Young sea turtles of the pelagic Sargassum-dominated drift community: habitat use, population density, and threats. Mar Ecol Prog Ser 463:1-22

Witt MJ, Bonguno EA, Broderick AC, Coyne MS and others (2011) Tracking leatherback turtles from the world's largest rookery: assessing threats across the South Atlantic. Proc R Soc B 278:2338-2347

Wyneken J (1997) Sea turtle locomotion: mechanics, behavior, and energetics. In: Lutz PL, Musick JA (eds) The biology of sea turtles. CRC Marine Science Series, CRC Press, Boca Raton, FL, p 165-198 